University of Nebraska - Lincoln

DigitalCommons@University of Nebraska - Lincoln

\title{
CQESTR Simulation of Management Practice Effects on Long- Term Soil Organic Carbon
}

\author{
Y. Liang \\ H.T. Gollany \\ R.W. Rickman \\ S.L. Albrecht \\ R.F. Follet
}

See next page for additional authors

Follow this and additional works at: https://digitalcommons.unl.edu/usdaarsfacpub

This Article is brought to you for free and open access by the U.S. Department of Agriculture: Agricultural Research Service, Lincoln, Nebraska at DigitalCommons@University of Nebraska - Lincoln. It has been accepted for inclusion in Publications from USDA-ARS / UNL Faculty by an authorized administrator of DigitalCommons@University of Nebraska - Lincoln. 
Authors

Y. Liang, H.T. Gollany, R.W. Rickman, S.L. Albrecht, R.F. Follet, W.W. Wilhelm, J.M. Novak, and C.L. Douglas Jr. 


\section{CQESTR Simulation of Management Practice Effects on Long-Term Soil Organic Carbon}

\author{
Y. Liang \\ Dep. of Biological and Agricultural Engineering \\ Cooperative Extension Service \\ Univ. of Arkansas \\ Fayetteville, AR 72701-1201

\section{H. T. Gollany* \\ R. W. Rickman (retired)} \\ S. L. Albrecht \\ USDA-ARS \\ Columbia Plateau Conserv. Research Center \\ P.O. Box. 370 \\ Pendleton, OR 97801
}

\section{R. F. Follett \\ USDA-ARS \\ Soil Plant Nutrient Research Center \\ Fort Collins, CO 80526}

\section{W. W. Wilhelm \\ USDA-ARS \\ Agroecosystem Management Research Unit \\ Lincoln, NE 68583}

\section{J. M. Novak}

USDA-ARS

Coastal Plains Soil, Water and Plant Res. Center

Florence, SC 29501

\author{
C. L. Douglas, Jr. (retired) \\ USDA-ARS \\ Columbia Plateau Conserv. Research Center \\ P.O. Box. 370 \\ Pendleton, OR 97801
}

\begin{abstract}
Management of soil organic matter (SOM) is important for soil productivity and responsible utilization of crop residues for additional uses. CQESTR, pronounced "sequester," a contraction of "C sequestration" (meaning $\mathrm{C}$ storage), is a C balance model that relates organic residue additions, crop management, and soil tillage to SOM accretion or loss. Our objective was to simulate SOM changes in agricultural soils under a range of climate and management systems using the CQESTR model. Four long-term experiments (Champaign, IL, >100 yr; Columbia, MO, >100 yr; Lincoln, NE, 20 yr; Sidney, NE, 20 yr) in the United States under various crop rotations, tillage practices, organic amendments, and crop residue removal treatments were selected for their documented history of the long-term effects of management practice on SOM dynamics. CQESTR successfully simulated a substantial decline in SOM with $50 \mathrm{yr}$ of crop residue removal under various rotations at Columbia and Champaign. The increase in SOM following addition of manure was simulated well; however, the model underestimated SOM for a fertilized treatment at Columbia. Predicted and observed values from the four sites were significantly related $\left(r^{2}=0.94, n=113, P<0.001\right)$, with slope not significantly different from 1 . Given the high correlation of simulated and observed SOM changes, CQESTR can be used as a reliable tool to predict SOM changes from management practices and offers the potential for estimating soil $\mathrm{C}$ storage required for $\mathrm{C}$ credits. It can also be an important tool to estimate the impacts of crop residue removal for bioenergy production on SOM level and soil production capacity.
\end{abstract}

Abbreviations: CC, continuous corn; $\mathrm{CH}$, chisel plow; MP, moldboard plow; NT, no-till; SOC, soil organic carbon; SOM, soil organic matter; ST, stubble mulch.
$T^{\mathrm{s}}$ The conversion of native forests and grasslands to agricultural lands would appropriately be characterized as an extensive ecological disturbance, through the release of $\mathrm{CO}_{2}$ to the atmosphere from $\mathrm{C}$ formerly stored as SOM. The loss of SOM as a result of this

Soil Sci. Soc. Am. J. 72:1486-1492

doi:10.2136/sssaj2007.0154

Received 30 April 2007.

*Corresponding author (hero.gollany@ars.usda.gov).

(c) Soil Science Society of America

677 S. Segoe Rd. Madison WI 53711 USA

All rights reserved. No part of this periodical may be reproduced or transmitted in any form or by any means, electronic or mechanical, including photocopying, recording, or any information storage and retrieval system, without permission in writing from the publisher. Permission for printing and for reprinting the material contained herein has been obtained by the publisher. conversion is well documented (Huggins et al., 1998; Liebig et al., 2005; Paustian et al., 1998; Post and Kwon, 2000; Rasmussen and Albrecht, 1997). An estimated $5 \mathrm{Pg}\left(10^{15} \mathrm{~g}\right)$ of $\mathrm{C}$ has been lost from U.S. soils as a result of cultivation (Lal et al., 1998). The amount of soil organic $\mathrm{C}$ (SOC) in an agroecosystem is governed by the difference between inputs of organic matter and outputs through mineralization, loss and deposition by erosion, and translocation of dissolved organic C through the soil (Campbell et al., 1996; Mertens et al., 2007). Soil C in its stable form as SOM responds gradually to agricultural management changes. Long-term field studies with repeated additions or removals of $\mathrm{C}$ sources are ideal to examine SOM changes (Gollany et al., 2006). Data from long-term field studies, with establishments dating back to 1876 , have provided much information on a range of agricultural crops and management practices. In an effort to characterize long-term changes in SOM, simulation models (Huggins et al., 1998; Paustian et al., 
1998; Rickman et al., 2001, 2002) have been used to describe and predict the short- and long-term effects of management controlling SOM turnover.

Understanding the long-term effects of management practices on $\mathrm{C}$ is fundamental to developing strategies for maintaining SOM and sustaining soil productivity. Soil organic matter has a beneficial influence on soil physical, chemical, and biological properties and contributes to crop productivity and soil quality (Jenkinson, 1991; Lal, 1997; Power et al., 1986). There is a growing interest in utilizing soil to store $\mathrm{C}$ as stable SOM to reduce $\mathrm{CO}_{2}$ levels in the atmosphere, with implications for the greenhouse effect and global warming (Lal et al., 1998; Paustian et al., 1995). Recently, there has been an increasing interest in using agricultural products (e.g., grain and residues) as feedstock for biofuel production (DiPardo, 2002). Furthermore, crop producers, biomass ethanol producers, and action agencies need guidance to determine the amount of crop residue that must remain on the soil to prevent soil $\mathrm{C}$ depletion and sustain soil functionality and productive capacity (Perlack et al., 2005; Lal, 2007).

The CQESTR model was developed to illustrate the effect of management practices on short- and long-term trends of SOM (Rickman et al., 2001, 2002) using readily available input data at the field scale. CQESTR was successful in predicting soil C trends in temperate regions (Rickman et al., 2002). In this study, we used CQESTR to simulate SOM changes with crop rotations under various fertility and tillage practices, as well as large-scale crop residue removal from agricultural lands; the results were compared with measured responses. Our objective was to simulate $\mathrm{SOM}$ changes in agricultural soils under various management systems and climates using the CQESTR model. Four long-term experiments with several management systems including crop rotations, tillage practices, and organic amendments, as well as crop residue removal, were selected for their documented history of management and SOM measurements to examine the ability of the CQESTR model to simulate the long-term effects of management practice on SOM dynamics.

\section{MATERIALS AND METHODS Site Descriptions}

The four long-term (Champaign, IL, >100 yr; Columbia, MO, >100 yr; Lincoln, NE, 20 yr; Sidney, NE, 20 yr) cropping experiment sites used in evaluating CQESTR are described in Table 1. These studies represent a variety of crop rotations, tillage practices, fertility conditions (e.g., manure addition), and crop residue removal rates and their effects on grain yields and soil C dynamics (Buyanovsky et al., 1997; Darmody and Peck, 1997; Lyon et al., 1997; Paul et al., 1997; Wilhelm and Wortmann, 2004). The agricultural cropping experiments ranged from 20 to $100 \mathrm{yr}$ in duration, with a range of mean annual temperature $\left(8-12^{\circ} \mathrm{C}\right)$, precipitation $(380$ $916 \mathrm{~mm}$ ), soil texture (silty clay loam, loam, and silt loam), and soil drainage class (moderately drained and well drained).

Sanborn Field $\left(38^{\circ}\right)^{\prime} \mathrm{N}$, $93^{\circ} 3^{\prime} \mathrm{W}$ ) at Columbia, MO, was established in 1888 (Buyanovsky et al., 1997). The soil is a Mexico silt loam (fine, smectitic, mesic Vertic Epiaqualf), grading into a Lindley loam (fine-loamy, mixed, superactive, mesic Typic
Hapludalf), developed in loess over old glacial till under tallgrass prairie. The plow layer contained 5 to $10 \%$ sand, 70 to $80 \%$ silt, and 10 to $20 \%$ clay. The land was in pasture with scattered elm (Ulmus americana L.) trees and buck brush (Ceanothus sanguineus L.) before plot establishment. Cropping systems used in this assessment were continuous corn (Zea mays L.), continuous winter wheat (Triticum aestivum L.), and continuous oat (Avena sativa L.) as the major grain crops and a 3-yr rotation of corn-wheat-clover (Trifolium pretense L.). The cropping systems were not replicated. Primary tillage consisted of fall moldboard plowing (20-cm depth) followed by secondary disk tillage and a harrow in spring. Fertilizer treatments included barnyard manure applied at $13.4 \mathrm{Mg} \mathrm{ha}^{-1} \mathrm{yr}^{-1}$, and $\mathrm{NH}_{4} \mathrm{NO}_{3}(34-0-0)$ before 1950 and later as 50, 8.74, and $16.6 \mathrm{~kg} \mathrm{ha}^{-1}$ of N, P, and K in accord with soil test and plant composition data. The grain crops were harvested at maturity either by hand or using current farming technology. Crop residues were removed from the plots before 1950 and only stubble and root residues were returned to the soil. Ninety percent of the aboveground biomass was assumed to be removed from the fields in the model simulation. After 1950, straw and stover from the wheat and corn plots were retained and uniformly spread and incorporated. Simulations of manure and fertilizer treatments were performed for $75 \mathrm{yr}$ (1915-1990).

The Morrow Plots ( $40^{\circ} 1^{\prime} \mathrm{N}, 88^{\circ} 1^{\prime} \mathrm{W}$ with 224-m elevation) at Champaign, IL, were established in 1876 (Darmody and Peck, 1997). The soil is a Flanagan silt loam (fine, smectitic, mesic Aquic Argiudoll), developed in loess over loamy glacial till under tallgrass prairie vegetation. Topsoil $(0-15 \mathrm{~cm})$ contains about $8 \%$ sand, $67 \%$ silt, and $25 \%$ clay. Tile drainage lines were installed in the plot borders in 1904 to improve soil drainage. Cropping systems were continuous corn (CC), corn-oat, and corn-oatclover rotations. In 1967, soybean [Glycine max (L.) Merr.] replaced oat in the corn-oat rotation. All plots were under conventional moldboard plow tillage. There was no randomized replication. The plots were divided into four subplots per rotation. Fertilizer treatments were subplots of the cropping system treatments. Control (no fertilizer) or manure treatments for each rotation were assigned to two or three subplots. Soil organic $\mathrm{C}$ contents were reported individually from these plots, but yields were reported as averages. Starting in 1904, a fertilizer treatment consisting of limestone, barnyard manure, and P was applied to one half of each plot. From 1876 until 1955, grain, straw, stover, and hay were removed while crop stubble and root residues were returned to the soil. From 1955 on, all crop residues were returned to selected subplots and in 1967 to all subplots.

The tillage-rotation study at the Rogers Memorial Farm $\left(40^{\circ} 5^{\prime} \mathrm{N}\right.$, $\left.96^{\circ} 4^{\prime} \mathrm{W}\right)$, Lincoln, NE, was established in 1981. The soil is a Sharpsburg silty clay loam (fine, smectitic, mesic Typic Argiudoll), developed in loess under grass prairie vegetation. Primary tillage treatments were moldboard plow (MP), tandem disk, chisel plow (CH), subsoil (rip), ridge-till, and no-till (NT) under continuous corn. In 1986, crop rotations of CC, continuous soybean, and a corn-soybean rotation were initiated in each tillage practice and have remained unchanged to date (Wilhelm and Wortmann, 2004). The experimental design for each block was a randomized complete

Table 1. Characteristics of the four long-term experiment sites used in CQESTR evaluation.

\begin{tabular}{|c|c|c|c|c|c|}
\hline \multirow{2}{*}{ Location } & \multirow{2}{*}{ Establishment } & \multirow{2}{*}{ Durationt } & \multirow{2}{*}{$\begin{array}{l}\text { Mean annual } \\
\text { precipitation }\end{array}$} & \multicolumn{2}{|c|}{ Mean annual temperature } \\
\hline & & & & Min. & Max. \\
\hline & & $\mathrm{yr}$ & $\mathrm{mm}$ & 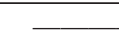 & $\bar{u}$ \\
\hline Columbia, MO (Sanborn Field) & 1888 & $>100$ & 916 & -1.5 & 26.0 \\
\hline Champaign, IL (Morrow Plots) & 1876 & $>100$ & 939 & -2.9 & 24.2 \\
\hline Lincoln, NE (Rogers Farm) & 1981 & 20 & 717 & -5.0 & 26.0 \\
\hline Sidney, NE & 1970 & 20 & 380 & 0.2 & 16.7 \\
\hline
\end{tabular}

t Time period for reported data used in simulation. 


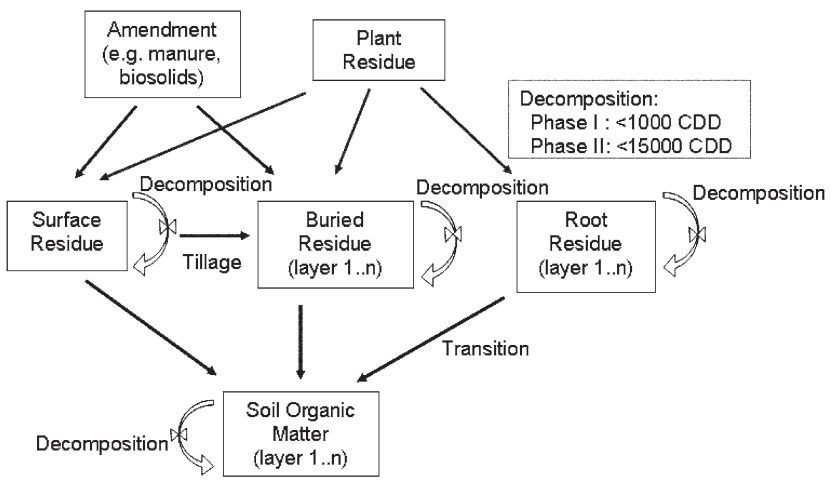

Fig. 1. Flow diagram for the CQESTR model. The empty arrows with valve symbols represent the computed change in mass on a daily basis. The solid arrows depict biomass additions to the residue pools or transfers from the residue pools to the stable soil organic matter pool. CDD is the cumulative degree days or thermal time.

block (six blocks) with a split-plot arrangement of treatments, with tillage practice assigned to whole plots and crop rotations to subplots.

A long-term tillage experiment was established near Sidney $\left(41^{\circ} 1^{\prime}\right.$ $\left.\mathrm{N}, 102^{\circ} 6^{\prime} \mathrm{W}\right), \mathrm{NE}$, in 1970 to compare three fallow tillage management practices - MP, stubble-mulch (ST), and NT - in a winter wheat-fallow system (Lyon et al., 1997). The soil is a Duroc loam (fine-silty, mixed, superactive, mesic Pachic Haplustoll), derived from mixed loess and alluvium. The plow layer of the native sod contained about $40 \%$ sand, $35 \%$ silt, and $25 \%$ clay. The land was in native mixed prairie sod until 1969 , and a native grass plot was maintained in each replication to serve as a control. For the MP treatment, a moldboard plow was used to a depth of approximately $15 \mathrm{~cm}$ followed by two to three operations with a field cultivator, and then one or two operations with a rotary rodweeder during the 14-mo fallow period. Stubble-mulch fallow treatments were performed with 90 - to 150 -cm sweeps two to four times a year to a maximum depth of approximately $10 \mathrm{~cm}$, followed by one or two operations with a rotary rodweeder. Seed planting was the only operation used in the NT treatment that caused soil disruption. The experimental design was a randomized complete block with three replications.

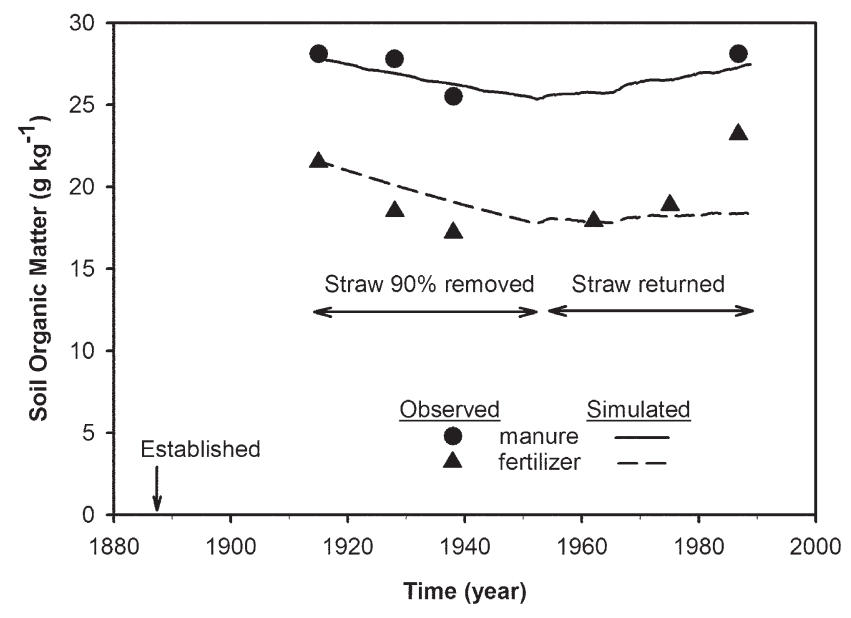

Fig. 2. Simulated and observed soil organic matter dynamics in the top $0-$ to $20-\mathrm{cm}$ soil layer for continuous winter wheat under moldboard plow tillage at Sanborn Field in Columbia, MO. Wheat straw was removed during harvest before 1950, and retained afterward. The vertical arrow indicates the year of establishment of the experiment.
More details of the experiments and descriptions of the sites are reported in the original references (Buyanovsky et al., 1997; Darmody and Peck, 1997; Lyon et al., 1997; Paul et al., 1997; Wilhelm and Wortmann, 2004).

\section{Estimation of Soil Organic Matter Maintenance Requirements}

Minimum crop residue and organic amendments required to prevent SOM decline were calculated for six treatments in the Morrow study. The relationship between SOM change and the corresponding estimate of total crop residue and manure applied for each treatment was calculated by partitioning the simulation data into a residueremoval phase (the segment before 1955) and a residue-return phase (the segment after 1955). The mean annual change of simulated SOM $\left(\mathrm{g} \mathrm{kg}^{-1} \mathrm{yr}^{-1}\right)$ for each treatment within each segment was calculated as the difference between initial and final SOM content:

$$
\Delta S O M=\left(S_{\mathrm{fOM}}-\mathrm{SOM}_{\mathrm{i}}\right) / t
$$

where $\mathrm{SOM}_{\mathrm{f}}$ is the calculated final SOM content $\left(\mathrm{g} \mathrm{kg}^{-1}\right), \mathrm{SOM}_{\mathrm{i}}$ is the calculated initial SOM content $\left(\mathrm{g} \mathrm{kg}^{-1}\right)$, and $t$ is the number of years.

\section{Model Description}

CQESTR is a process-based model, in which each organic residue addition is tracked separately, without partitioning, according to its placement on the surface or buried in the soil (Fig. 1). The CQESTR model operates on a daily step (Rickman et al., 2001). The major site input variables include mean monthly air temperature and monthly total precipitation, crop rotation and annual yields (including aboveground and belowground biomass), organic amendments (i.e., manure), tillage information, $\mathrm{N}$ content of crop residues and organic amendments, root distribution characteristics of the crops, the number and thickness (depth) of soil layers, and the initial SOM content and bulk density of each layer. All input variables including crop rotation, annual yields, organic amendments, and tillage information were obtained from published literature and organized in crop management files associated with the $c$ factor of the Revised Universal Soil Loss Equation (RUSLE, Version 1, Renard et al., 1996).

\section{RESULTS AND DISCUSSION Effect of Biomass or Residue Removal on Soil Organic Matter}

The loss of SOM after converting native tallgrass prairie to production agriculture at Sanborn Field was well predicted by the CQESTR model (Fig. 2). The rapid decline in SOM was caused by crop residue removal before 1950 . When $90 \%$ of the crop residue was removed at harvest for about $50 \mathrm{yr}$, SOM decreased even in fertilized and manure treatments. The decline in SOM concentration from long-term corn stover removal has been documented in other studies in Minnesota (Allmaras et al., 2004; Bloom et al., 1982; Wilts et al., 2004), Iowa (Larson et al., 1972), Wisconsin (Vanotti et al., 1997), Indiana (Barber, 1979), Ohio (Blanco-Canqui et al., 2006a), and Michigan (Vitosh et al., 1997). For the Sanborn Field, losses were greatest during the first few decades of land conversion under the fertilized treatment. This could be due to agronomic practices, especially before 1940, when crop residue was removed during harvest and used for livestock feed and bedding. There were few fertilizer inputs other than livestock and green manure to return nutrients removed by the harvest of grain and biomass (Allmaras et al., 1998). Only when the straw was retained after 1950 did the 
SOM concentration increase. The upward trends in SOM during the period when wheat straw residue was retained on the land, for both manure and control unreplicated treatments, were simulated by CQESTR. The model underestimated SOM in 1989 after residue was retained in the fertilized treatment. The reason for this discrepancy is not understood. This could be due to an error in sample collection or handling, or perhaps some other factor that could not be accounted for in the model.

At the Morrow Plots, return of crop residue after 1955 resulted in a reduced rate of decline or a stabilization of SOM during subsequent years (Fig. 3). Organic biomass addition, such as barnyard manure, resulted in greater SOM in all three rotations. Manure application in modern cropping systems has been known to sustain or increase SOM (Rickman et al., 2001; Tester, 1990; VandenBygaart et al., 2003). CQESTR simulated the observed SOM values well for the subplots of three crop rotations at the Morrow Plots except for the corn-oat-clover rotation without manure application (Fig. 3c). The reason for the relatively large discrepancy between simulated and observed SOM values from the corn-oat rotation (Fig. 3b, from about 1930-1980) with manure treatment is unclear. Perhaps CQESTR underestimated the contribution of oat biomass to SOM content before the 1960s because of an unreliable plant parameter used in CQESTR, such as the root/shoot ratio. Huggins et al. (1998) suggested that factors in addition to $\mathrm{C}$ inputs to these plots were controlling management-induced variation in SOM levels (i.e., SOM decay rates). Crop management practices that were beneficial to grain and residue production, such as organic amendments or crop residue retention in the field, improved observed and simulated SOM content. Management practices that removed crop residue (straw or stover) without organic amendments (i.e., manure), however, decreased SOM content (Fig. 2 and 3). Crop residue removal not only depletes SOM but also has adverse effects on other soil physical and chemical properties (Balesdent et al., 2000; Blanco-Canqui et al., 2006b). Blanco-Canqui et al. (2006a,b) reported that stover removal rates as low as $1.25 \mathrm{Mg} \mathrm{ha}^{-1}$ reduced SOC and degraded soil structure properties even within $1 \mathrm{yr}$ for silt loam soils in two long-term NT experiments. They also reported the importance of soil type, soil texture classes, and tillage interactions to SOM accumulation.

\section{Effect of Tillage and Crop Rotation on Soil Organic Matter}

The interactions of crop rotation and tillage in corn and soybean systems under NT and MP in eastern Nebraska were simulated during $20 \mathrm{yr}$ (Fig. 4). CQESTR predicted an increase of $6 \%$ in SOM values in the 0 - to $30-\mathrm{cm}$ layer after conversion from MP to NT, under continuous corn, in which the residue amount returned to the soil was essentially the same for NT and MP. Karlen and Stott (1994) found that NT and CH systems accumulated a greater quantity of SOC in the top 30-cm soil layer relative to the MP system. Conversion to NT from tilled practices (especially plowed systems) improved the SOM content in the topsoil across diverse soils (West and Post, 2002). Simulated and observed SOM values increased by 2.5 and 4.5 $\mathrm{g} \mathrm{kg}^{-1}$, respectively, in the 0 - to $30-\mathrm{cm}$ depth for continuous corn under a no-till management system between 1985 and 1999; for continuous soybean under a moldboard plow system, simulated and observed SOM values decreased by 1.8 and 2.0 $\mathrm{g} \mathrm{kg}^{-1}$, respectively, in the 0 - to $30-\mathrm{cm}$ depth during the same time period. Similar results were found in other long-term tillage comparisons of continuous corn and corn-soybean rotations in Ohio (Lal et al., 1994; Dick and Durkalski, 1997).

Trends in SOM contents in two soil layers (0-10- and 10-20$\mathrm{cm}$ depths) under winter wheat-fallow and three tillage systems were simulated for the Sidney, NE, experiment (Fig. 5a and 5b). In 1990, simulated SOM values ranged from 32.3 to 33.3 and 30.7 to $32.2 \mathrm{~g}$ $\mathrm{kg}^{-1}$ for NT and ST, respectively (Fig. 5a). Simulated SOM content increased from the site initial value of $30.4 \mathrm{~g} \mathrm{~kg}^{-1}$ to 31.0 and $32.5 \mathrm{~g}$ $\mathrm{kg}^{-1}$ for ST and NT, respectively. Simulated SOM values indicated that reduced tillage after conversion from native grass in 1970 (Lyon et al., 1997; Peterson et al., 1998) to ST or NT resulted in reduced

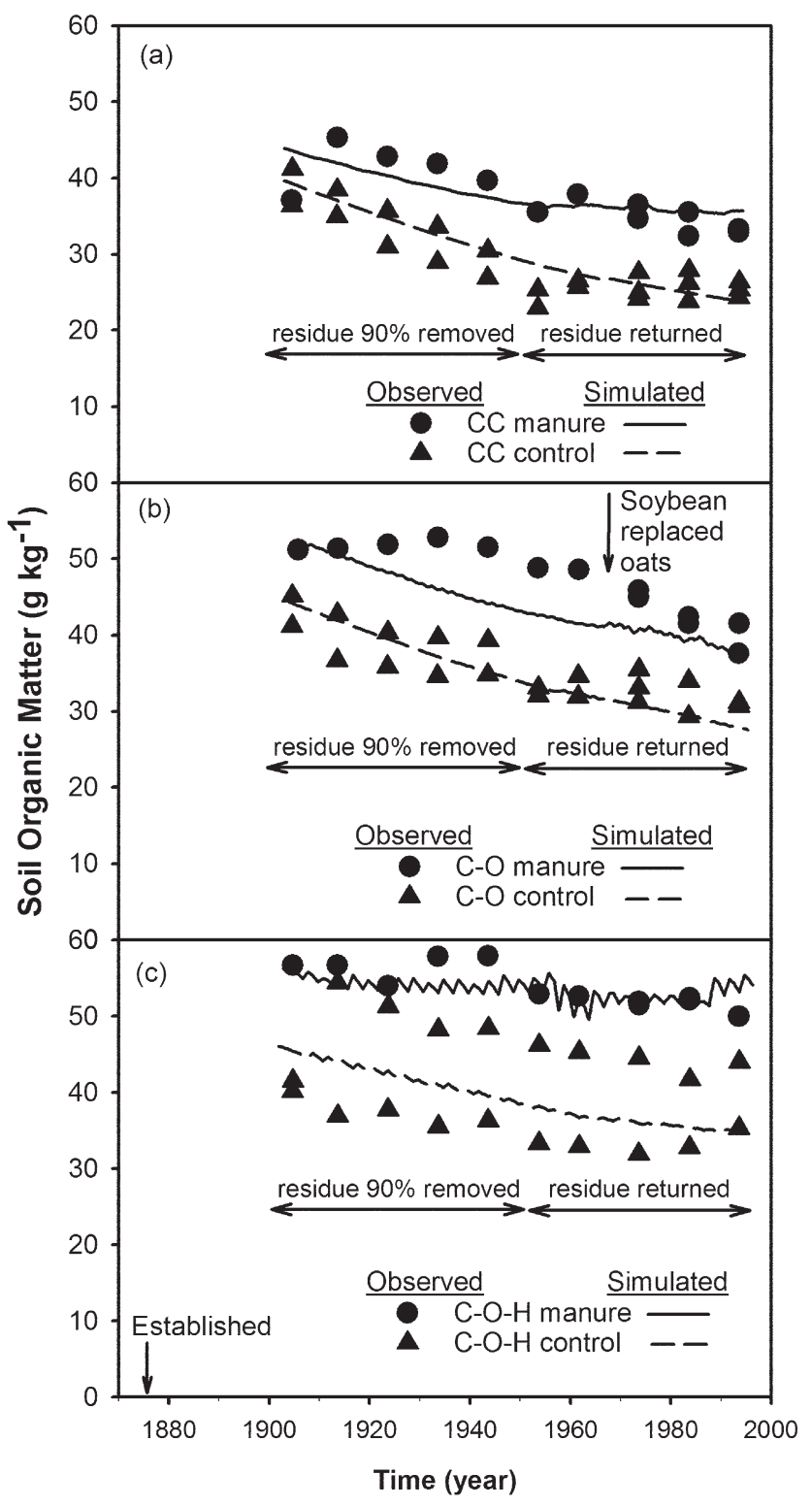

Fig. 3. Simulated and observed soil organic matter dynamics, in the top 0- to 15-cm soil layer for: (a) continuous corn (CC); (b) corn-oat rotation (C-O); and (c) corn-oat-clover rotation $(\mathrm{C}-\mathrm{O}-\mathrm{H})$ under moldboard plow tillage at the Morrow Plots in Champaign, IL. Corn stover and wheat straw were removed during harvest before 1955, but retained afterward. Control (no fertilizer) or manure treatments for each rotation were assigned to two or three subplots. Soil organic matter observations were reported separately from each subplot that received identical treatment but yields were reported as averages. The vertical arrow indicates year of establishment of experiment. 


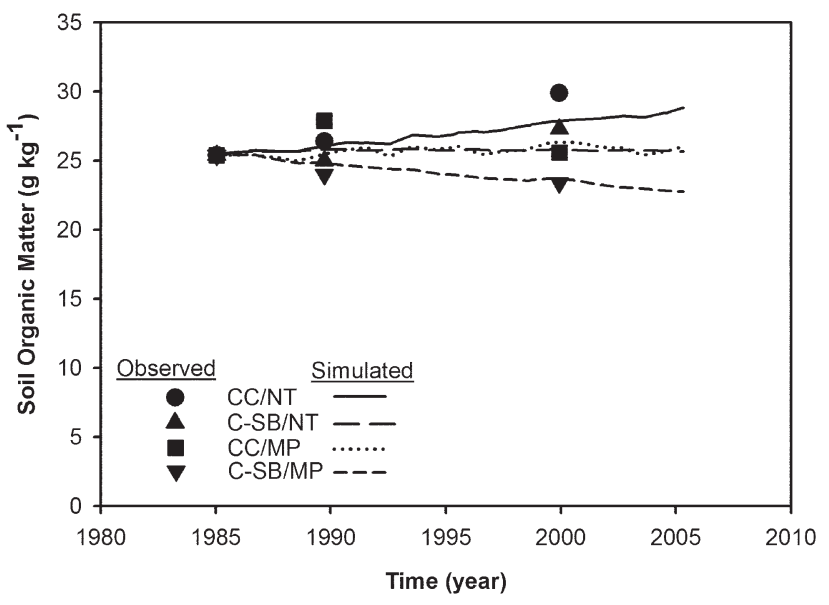

Fig. 4. Simulated and observed soil organic matter dynamics in the top 0- to $30-\mathrm{cm}$ soil layer for continuous corn (CC) and continuous soybean (C-SB) under moldboard plow (MP) and no-till (NT) treatments at Rogers Memorial Farm in Lincoln, NE.

soil C losses in the winter wheat-fallow system. Simulated values for MP with a range of 27.3 to $28.9 \mathrm{~g} \mathrm{~kg}^{-1}$ in 1990 indicated SOM losses, although the magnitude of simulated SOM discrepancy between reduced tillage and MP were not as large as observed values. Since the difference in primary crop productivity between the three tillage systems was not pronounced (Lyon et al., 1997), C accretion under NT was believed to be a result of reduced decomposition because of a combination of low mean annual precipitation (Table 1) and soil texture (Table 2). There were no differences in the simulated SOM trends for the NT and ST systems in the 10- to 20-cm depth (Fig. 3b). Wander et al. (1998) reported that tillage impacted the depth distribution of SOC in three Illinois soils. Generally, NT increased SOC and particulate organic matter compared with MP (moldboard plow after corn and chisel plow after soybean) in the surface $5 \mathrm{~cm}$, but decreased in the $5-$ to $17.5-\mathrm{cm}$ depth. The benefits of NT on SOC sequestration varied with cropping system and depth of measurement (West and Post, 2002).

\section{Comparison of Observed and Simulated Soil Organic Matter Values}

Soil organic matter values from the four agricultural sites were used to assess the CQESTR model simulation of SOM changes under a range of climate and management systems (Fig. 6). Regression analysis of 113 pairs of predicted and measured SOM values from the four sites were closely related $\left(r^{2}\right.$

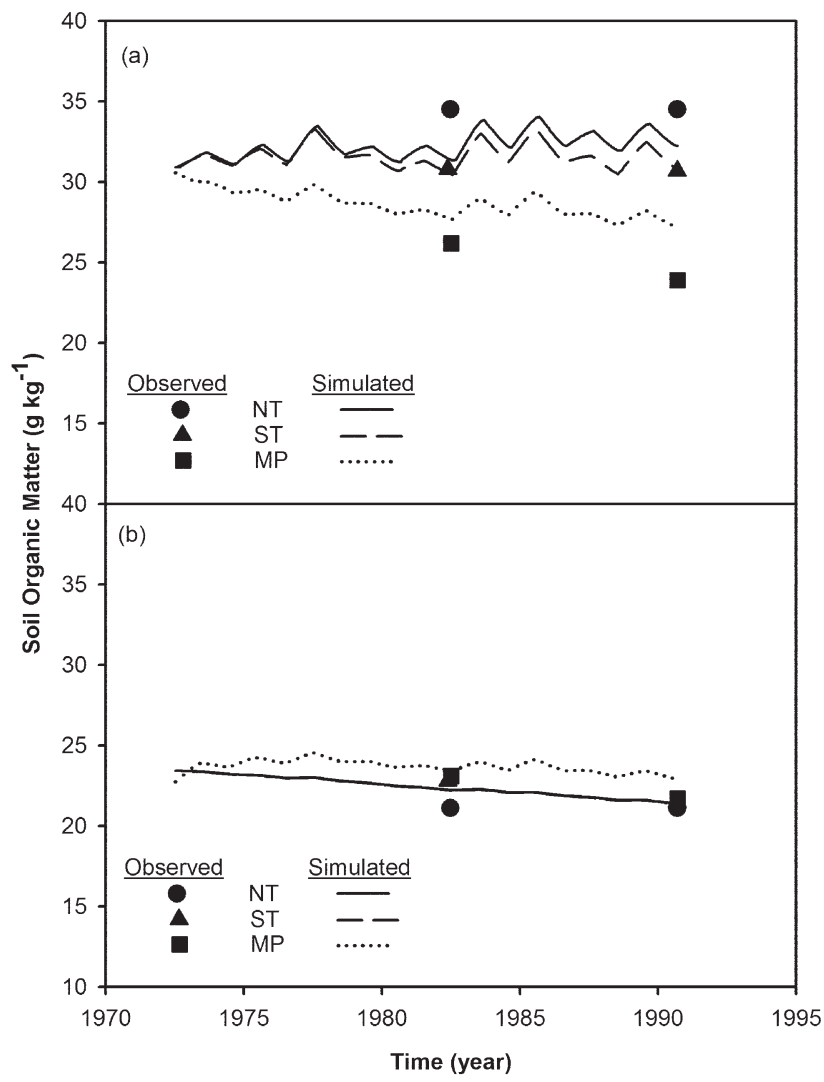

Fig. 5. Simulated and observed soil organic matter dynamics in the (a) 0-10 cm and (b) $10-20 \mathrm{~cm}$ soil layers for winter wheat-fallow rotations under three tillage treatments at Sidney, NE (MP, moldboard plowed to $15-\mathrm{cm}$ depth; ST, stubble-mulch with 90-150$\mathrm{cm}$ sweeps to $10-\mathrm{cm}$ depth performed two to four times a year; NT, no-till operation except for coulter-type drill for seeding).

$=0.94, P<0.001)$, with slope not significantly different from $1(P<0.001)$, demonstrating the capacity of CQESTR to predict long-term organic matter dynamics for these sites under a range of climate and management practices.

\section{Estimate of Minimum Crop Residue or Organic Amendments for Soil Organic Matter Maintenance}

The relationship between the SOM changes and the corresponding estimates of total crop residue and manure applied to soils (Fig. 7) suggested that a minimum of $8.0 \mathrm{Mg} \mathrm{ha}^{-1} \mathrm{yr}^{-1}$ of crop residue and organic amendments (4.6 $\mathrm{Mg} \mathrm{C} \mathrm{ha}^{-1} \mathrm{yr}^{-1}$ ) was required to prevent SOM decline in the plots at the Morrow site. In

Table 2. Management practices, soil sampling, soil texture, and drainage classes for the four long-term studies.

\begin{tabular}{|c|c|c|c|c|c|c|c|}
\hline Site & Crop rotationt & Management $\ddagger$ & $\begin{array}{c}\text { Sampling } \\
\text { depth }\end{array}$ & $\begin{array}{c}\text { Earliest } \\
\text { sample§ }\end{array}$ & $\begin{array}{l}\text { Latest } \\
\text { sample }\end{array}$ & Soil texture & Soil drainage class \\
\hline \multicolumn{8}{|c|}{$\mathrm{cm}$} \\
\hline Columbia MO (Sanborn Field) & W & MP, fertilizer, manure & $0-20$ & 1915 & 1986 & silt loam or loam & moderately drained \\
\hline Champaign, IL (Morrow Plots) & C, C-O, C-O-hay & $\begin{array}{l}\text { MP, two fertility levels, } \\
\text { residue removal } \\
\text { before } 1955\end{array}$ & $0-15$ & 1904 & 1993 & silt loam & moderately drained \\
\hline Lincoln, NE (Rogers Farm) & $\mathrm{C}, \mathrm{SB}, \mathrm{C}-\mathrm{SB}, \mathrm{SB}-\mathrm{C}$ & $\mathrm{NT}, \mathrm{MP}$ & $0-30$ & 1985 & 1999 & silty clay loam & moderately drained \\
\hline Sidney, NE & W-F & $\mathrm{MP}, \mathrm{ST}, \mathrm{NT}$ & $\begin{array}{r}0-10 \\
10-20 \\
\end{array}$ & 1982 & 1991 & loam & well drained \\
\hline
\end{tabular}

+C, corn; F, fallow; O, oat; SB, soybean; W, wheat.

‡ MP, moldboard plow; ST, stubble-mulch; NT, no-till.

$\S$ Earliest soil sample did not necessarily occur at the initiation of an experiment. 


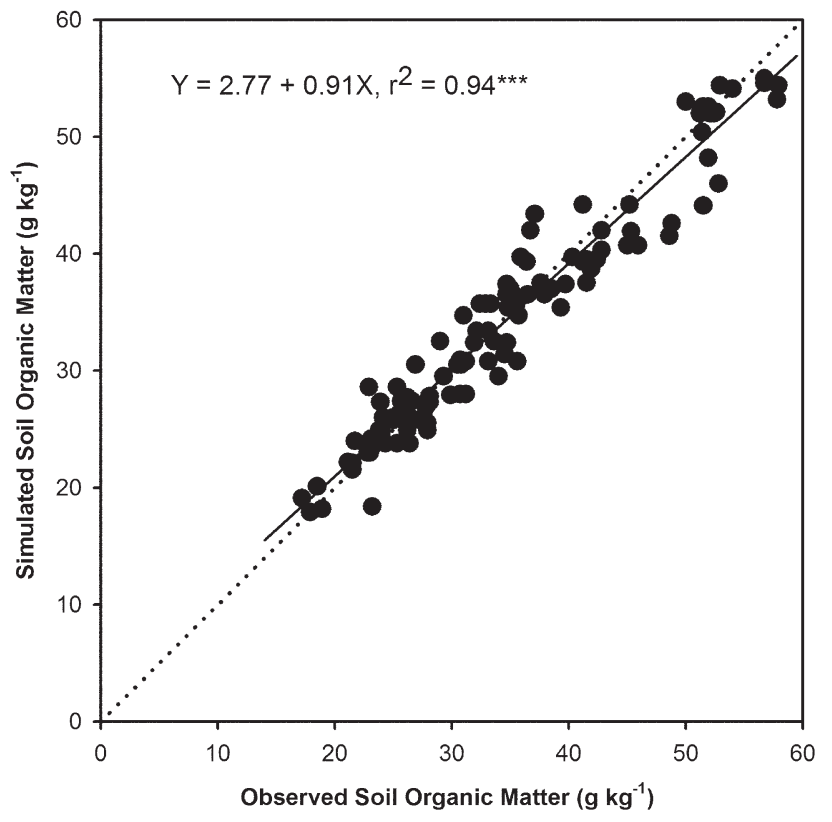

Fig. 6. Comparison of observed and simulated soil organic matter at four U.S. agricultural sites. The thin line represents equal values for simulated and observed data. ${ }^{* * *}$ Significant at the $\mathbf{0 . 0 0 1}$ probability level.

general, the rate of SOM change responds linearly to annual organic biomass input (Rasmussen and Collins, 1991). Carter et al. (1993) calculated that organic $\mathrm{C}$ input should exceed $3.0 \mathrm{Mg} \mathrm{C} \mathrm{ha}^{-1} \mathrm{yr}^{-1}$ to prevent a decline in soil organic $\mathrm{C}$ for five wheat rotation sites across southern Australia, with soil texture ranging from sandy clay loam to sandy loam and loamy sand and climate conditions ranging from warm temperate dry summer to warm humid. Johnson et al. (2006) estimated a minimum required organic $\mathrm{C}$ input range of 1.2 to $4.0 \mathrm{Mg} \mathrm{C} \mathrm{ha}^{-1} \mathrm{yr}^{-1}$ for the Pacific Northwest (Oregon and Washington), while Rasmussen and Collins (1991) reported a value of $2.5 \mathrm{Mg} \mathrm{C} \mathrm{ha}^{-1} \mathrm{yr}^{-1}$ for a wheat-fallow rotation under conventional MP tillage for a silt loam soil in Oregon. CQESTR predicted the minimum required organic $\mathrm{C}$ inputs, which included belowground biomass but without estimates of rhizodeposition. These predictions might be closer to the required $\mathrm{C}$ inputs than those estimated only from aboveground crop biomass calculated from the harvest index. Averaged across major crops in the U.S. Midwest, Johnson et al. (2006) reported a minimum required organic $\mathrm{C}$ input of $2.5 \pm 1.0$ and $1.8 \pm 0.44 \mathrm{Mg} \mathrm{Cha}^{-1} \mathrm{yr}^{-1}$ for NT and $\mathrm{CH}$ tillage, respectively. Furthermore, moldboard plowed corn-based rotations had a higher $\mathrm{C}$ input requirement $\left(3.0 \pm 1.0 \mathrm{Mg} \mathrm{C} \mathrm{ha}^{-1} \mathrm{yr}^{-1}\right)$ than wheat-based rotations $\left(2.2 \pm 1.1 \mathrm{Mg} \mathrm{C} \mathrm{ha}^{-1} \mathrm{yr}^{-1}\right)$. This indicates that the amount of crop residue required for maintaining SOM concentration in different soils under a wide range of management and climatic conditions is different. Soils with high SOM concentration in well-managed lands require more residue or organic amendment input to maintain an SOM level than soil with a low native SOM concentration (Larson et al., 1972; Rasmussen and Collins, 1991). It is important that any crop residue removal for bioenergy production be based on sustainable management practices to maintain SOM and environmental quality (Wilhelm et al., 2004).

\section{CONCLUSIONS}

We demonstrated the CQESTR model's capability to simulate the effect of different crop rotation and tillage systems, or resi-

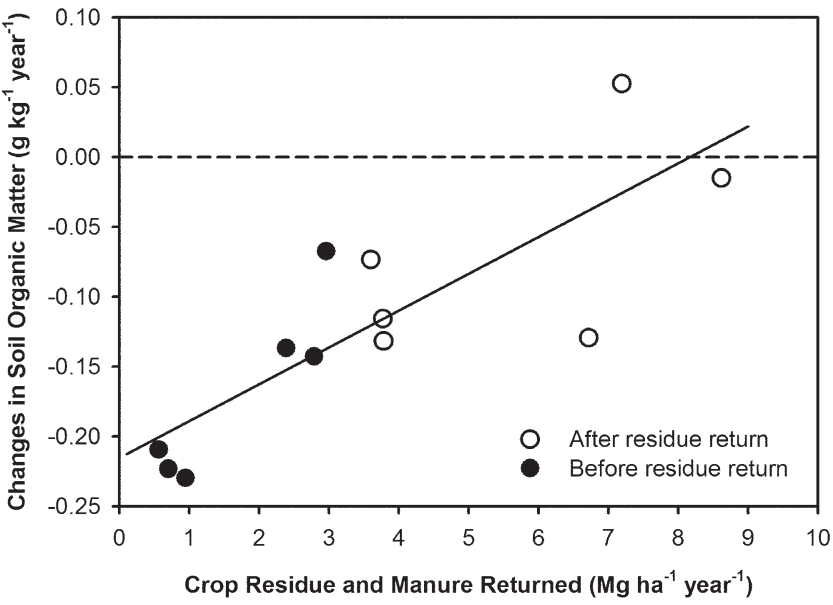

Fig. 7. Mean annual change in simulated soil organic matter in relation to estimated mean annual total crop residue and manure returned to the soil at the Morrow Plots. Each treatment was divided into a residue-removal phase (before 1955) and a residue-return phase (after 1955), with mean annual SOM change calculated separately.

due removal, on SOM. Specifically, the model successfully simulated the detrimental effect of $>50 \mathrm{yr}$ of crop residue removal on SOM dynamics. The relationship between the SOM changes and corresponding estimates of total crop residue and manure applied to soils suggests that a minimum of $8 \mathrm{Mg} \mathrm{ha}^{-1} \mathrm{yr}^{-1}$ of crop residue and organic amendment is required to maintain SOM level at the Morrow Plots. Management practices that increase biomass, limit inversion tillage, and return root and shoot biomass to the soil annually promote $\mathrm{C}$ accretion. The CQESTR model can be used to examine the expected effect of planned or proposed changes in agricultural management practices on soil $\mathrm{C}$ contents at the field scale. The use of CQESTR allows evaluation of management options so that sustainability can be considered along with soil productivity. More studies are needed to evaluate the CQESTR model's performance in predicting the amount of crop residue required to maintain the SOM concentration in different soils under a wide range of management and climatic conditions. The development of soil management practices that maintain adequate SOM for nutrient cycling, soil structure stability, and sufficient biomass to prevent erosion will be essential for decisions on land use for food, fiber, feed, and bioenergy.

\section{ACKNOWLEDGMENTS}

We thank Drs. Charlie Walthall and Michael Jawson for their support of the modeling effort. This publication is based on work supported by the U.S. Department of Agriculture-Agricultural Research Service under the ARS GRACEnet and REAP projects.

\section{REFERENCES}

Allmaras, R.R., D.R. Linden, and C.E. Clapp. 2004. Corn-residue transformations into root and soil carbon as related to nitrogen, tillage, and stover management. Soil Sci. Soc. Am. J. 68:1366-1375.

Allmaras, R.R., D.E. Wilkins, O.C. Burnside, and D.J. Mulla. 1998. Agricultural technology and adoption of conservation practices. p. 99-157. In F.J. Pierce and W.W. Frye (ed.) Advances in soil and water conservation. Sleeping Bear Press, Chelsea, MI.

Balesdent, J., C. Chenu, and M. Balabane. 2000. Relationship of soil organic matter dynamics to physical protection and tillage. Soil Tillage Res. 53:215-230.

Barber, S.A. 1979. Corn residue management and soil organic matter. Agron. J. 71:625-627. 
Blanco-Canqui, H., R. Lal, W.M. Post, R.C. Izaurralde, and L.B. Owens. 2006a. Rapid changes in soil carbon and structural properties due to stover removal from no-till corn plots. Soil Sci. 171:468-482.

Blanco-Canqui, H., R. Lal, W.M. Post, R.C. Izaurralde, and L.B. Owens. 2006b. Corn stover impacts on near-surface soil properties of no-till corn in Ohio. Soil Sci. Soc. Am. J. 70:266-278.

Bloom, P.R., W.M. Schuh, G.L. Malzer, W.W. Nelson, and S.D. Evans. 1982. Effect of nitrogen fertilizer and corn residue management on organic matter in Minnesota Mollisols. Agron. J. 74:161-163.

Buyanovsky, G.A., J.R. Brown, and G.H. Wagner. 1997. Sanborn Field: Effect of 100 years of cropping on soil parameters influencing productivity. p. 205226. In E.A. Paul et al. (ed.) Soil organic matter in temperate agroecosystems: Long-term experiments in North America. CRC Press, Boca Raton, FL.

Campbell, C.A., B.G. McConkey, R.P. Zentner, F.B. Dyck, F. Selles, and D. Curtin. 1996. Long-term effects of tillage and crop rotations on soil organic $C$ and total $\mathrm{N}$ in a clay soil in southwestern Saskatchewan. Can. J. Soil Sci. 76:395-401.

Carter, M.R., W.J. Parton, I.C. Rowland, J.E. Schultz, and G.R. Steed. 1993. Simulation of soil organic carbon and nitrogen changes in cereal and pasture systems of southern Australia. Aust. J. Soil Res. 31:481-491.

Darmody, R.G., and T.R. Peck. 1997. Soil organic changes through time at the University of Illinois Morrow Plots. p. 161-169. In E.A. Paul et al. (ed.) Soil organic matter in temperate agroecosystems: Long-term experiments in North America. CRC Press, Boca Raton, FL.

Dick, W.A., and J.T. Durkalski. 1997. No-till production agriculture and carbon sequestration in a Typic Fragiudalf soil of northeastern Ohio. p. 59-71. In R. Lal et al. (ed.) Management of carbon sequestration in soil. CRC Press, Boca Raton, FL.

DiPardo, J. 2002. Outlook for biomass ethanol production and demand. Available at www.eia.doe.gov/oiaf/analysispaper/pdf/biomass.pdf (verified 13 July 2008). Energy Inf. Admin., Washington, DC.

Gollany, H.T., R.R. Allmaras, S.M. Copeland, S.L. Albrecht, and C.L. Douglas, Jr. 2006. Incorporated source carbon and nitrogen fertilization effects on carbon storage and soluble silica in a Haploxeroll. Soil Sci. 171:585-597.

Johnson, J.M.F., R.R. Allmaras, and D.C. Reicosky. 2006. Estimating source carbon from crop residues, roots and rhizodeposits using the national grain-yield database. Agron. J. 98:622-636.

Huggins, D.R., G.A. Buyanovsky, G.H. Wagner, J.R. Brown, R.G. Darmody, T.R. Peck, G.W. Lesoing, M.B. Vanotti, and L.G. Bundy. 1998. Soil organic $\mathrm{C}$ in the tallgrass prairie-derived region of the Corn Belt: Effects of long-term crop management. Soil Tillage Res. 47:219-234.

Jenkinson, D.S. 1991. The Rothamsted long term experiments: Are they still of use? Agron. J. 83:2-10.

Karlen, D.L., and D.E. Stott. 1994. A framework for evaluating physical and chemical indicators of soil quality. p. 53-72. In J.W. Doran et al. (ed.) Defining soil quality for a sustainable environment. SSSA Spec. Publ. 35. SSSA and ASA, Madison, WI.

Lal, R. 1997. Residue management, conservation tillage and soil restoration for mitigating greenhouse effect by $\mathrm{CO}_{2}$-enrichment. Soil Tillage Res. 43:81-107.

Lal, R. 2007. Biofuels from crop residues. Soil Tillage Res. 93:237-238.

Lal, R., J.M. Kimble, R.F. Follett, and C.V. Cole. 1998. The potential of US cropland to sequester carbon and mitigate the greenhouse effect. Sleeping Bear Press, Ann Arbor, MI.

Lal, R., A.A. Mahboubi, and N.R. Fausey. 1994. Long-term tillage and rotation effects on properties of a central Ohio soil. Soil Sci. Soc. Am. J. 58:517-522.

Larson, W.E., C.E. Clapp, W.H. Pierre, and Y.B. Morachan. 1972. Effect of increasing amounts of organic residues on continuous corn: II. Organic carbon, nitrogen, phosphorus, and sulfur. Agron. J. 64:204-208.

Liebig, M.A., J.A. Morgan, J.D. Reeder, B.H. Ellert, H.T. Gollany, and G.E. Schumann. 2005. Greenhouse gas contributions and mitigation potential of agricultural practices in northwestern USA and western Canada. Soil Tillage Res. 83:25-52.

Lyon, D.J., C.A. Monz, R.E. Brown, and A.K. Metherell. 1997. Soil organic matter changes over two decades of winter wheat-fallow cropping in western Nebraska. p. 343-351. In E.A. Paul et al. (ed.) soil organic matter in temperate agroecosystems: Long-term experiments in North America. CRC Press, Boca Raton, FL.

Mertens, J., J. Vanderborght, R. Kasteel, T. Pütz, R. Merckx, J. Feyen, and E. Smolders. 2007. Dissolved organic carbon fluxes under bare soil. J. Environ. Qual. 36:597-606.
Paul, E.A., K. Paustian, E.T. Elliot, and C.V. Cole. 1997. Soil organic matter in temperate agroecosystems: Long-term experiments in North America. CRC Press, Boca Raton, FL.

Paustian, K., E.T. Elliot, and K. Killian. 1998. Modeling soil carbon in relation to management and climate change in some agroecosystems in central North America. p. 459-471. In R. Lal et al. (ed.) Soil processes and the carbon cycle. CRC Press, Boca Raton, FL.

Paustian, K., G.P. Robertson, and E.T. Elliot. 1995. Management impacts on carbon storage and gas fluxes $\left(\mathrm{CO}_{2}, \mathrm{CH}_{4}\right)$ in mid latitude cropland. p. 69-83. In $\mathrm{R}$ Lal et al (ed.) Soil Management and Greenhouse Effect. Lewis Publishers, Boca Raton, FL.

Perlack, R.D., L.L. Wright, A.F. Turhollow, R.L. Graham, B.J. Stokes, and D.C. Erbach. 2005. Biomass as feedstock for a bioenergy and bioproducts industry: The technical feasibility of a billion-ton annual supply. DOE/GO-1020052135 and ORNL/TM-2005/66. Oak Ridge Natl. Lab., Oak Ridge, TN.

Peterson, G.A., A.D. Halvorson, J.L. Havlin, O.R. Jones, D.J. Lyon, and D.L. Tanaka. 1998. Reduced tillage and increasing cropping intensity in the Great Plains conserves soil C. Soil Tillage Res. 47:207-218.

Post, W.M., and K.C. Kwon. 2000. Soil carbon sequestration and land-use change: Processes and potential. Global Change Biol. 6:317-327.

Power, J.F., W.W. Wilhelm, and J.W. Doran. 1986. Crop residue effects on soil environment and dryland maize and soybean production. Soil Tillage Res. 8:101-111.

Rasmussen, P.E., and S.L. Albrecht. 1997. Crop management effects on organic carbon in semi-arid Pacific Northwest soils. p. 209-219. In R. Lal et al. (ed.) Management of carbon sequestration in soil. CRC Press, Boca Raton, FL.

Rasmussen, P.E., and H.P. Collins. 1991. Long-term impacts of tillage, fertility and crop residue on soil organic matter in temperate semiarid regions. Adv. Agron. 45:93-134.

Renard, K.G., G.R. Foster, G.A. Weesies, D.K. McCool, and D.C. Yoder (coord.). 1996. Predicting soil erosion by water: A guide to conservation planning with the Revised Universal Soil Loss Equation (RUSLE). Agric. Handbk. 703. USDA, Washington, DC.

Rickman, R., C. Douglas, S. Albrecht, and J. Berc. 2002. Tillage, crop rotation, and organic amendment effect on changes in soil organic matter. Environ. Pollut. 116:405-411.

Rickman, R.W., C.L. Douglas, Jr., S.L. Albrecht, L.G. Bundy, and J.L. Berc. 2001. CQESTR: A model to estimate carbon sequestration in agricultural soils. J. Soil Water Conserv. 56:237-242.

Tester, C.F. 1990. Organic amendment effects on physical and chemical properties of a sandy soil. Soil Sci. Soc. Am. J. 54:827-831.

VandenBygaart, A.J., E.G. Gregorich, and D.A. Angers. 2003. Influence of agricultural management on soil organic carbon: A compendium and assessment of Canadian studies. Can. J. Soil Sci. 83:363-380.

Vanotti, M.B., L.G. Bundy, and A.E. Peterson. 1997. Nitrogen fertilizer and legumecereal rotation effects on soil productivity and organic matter dynamics in Wisconsin. p. 105-120. In E.A. Paul et al. (ed.) Soil organic matter in temperate agroecosystems: Long-term experiments in North America. CRC Press, Boca Raton, FL.

Vitosh, M.L., R.E. Lucas, and G.H. Silva. 1997. Long-term effects of fertilizer and manure on corn yield, soil carbon and other soil chemical properties in Michigan. p. 129-139. In E.A. Paul et al. (ed.) Soil organic matter in temperate agroecosystems: Long-term experiments in North America. CRC Press, Boca Raton, FL.

Wander, M.M., M.G. Bidart, and S. Aref. 1998. Tillage impacts on depth distribution of total and particulate organic matter in three Illinois soils. Soil Sci. Soc. Am. J. 62:1704-1711.

West, T.O., and W.M. Post. 2002. Soil organic carbon sequestration rates by tillage and crop rotation: A global data analysis. Soil Sci. Soc. Am. J. 66:1930-1946.

Wilhelm, W.W., J.M.F. Johnson, J.L. Hatfield, W.B. Voorhees, and D.R. Linden. 2004. Crop and soil productivity response to corn residue removal: A literature review. Agron. J. 96:1-17.

Wilhelm, W.W., and C.S. Wortmann. 2004. Tillage and rotation interactions for corn and soybean grain yield as affected by precipitation and air temperature. Agron. J. 96:425-432.

Wilts, A.R., D.C. Reicosky, R.R. Allmaras, and C.E. Clapp. 2004. Long-term corn residue effects: Harvest alternatives, soil carbon turnover, and rootderived carbon. Soil Sci. Soc. Am. J. 68:1342-1351. 